\title{
Building Information Modelling (BIM) Readiness of Construction Professionals: The Context of the Seychelles Construction Industry
}

DOI:

10.1108/JEDT-09-2020-0379

\section{Document Version}

Accepted author manuscript

Link to publication record in Manchester Research Explorer

Citation for published version (APA):

Adam, V., Manu, P., Mahamadu, A. M., Dziekonski, K., Kissi, E., Emuze, F., \& Lee, S. (2021). Building Information Modelling (BIM) Readiness of Construction Professionals: The Context of the Seychelles Construction Industry. Journal of Engineering, Design and Technology. https://doi.org/10.1108/JEDT-09-2020-0379

Published in:

Journal of Engineering, Design and Technology

\section{Citing this paper}

Please note that where the full-text provided on Manchester Research Explorer is the Author Accepted Manuscript or Proof version this may differ from the final Published version. If citing, it is advised that you check and use the publisher's definitive version.

\section{General rights}

Copyright and moral rights for the publications made accessible in the Research Explorer are retained by the authors and/or other copyright owners and it is a condition of accessing publications that users recognise and abide by the legal requirements associated with these rights.

\section{Takedown policy}

If you believe that this document breaches copyright please refer to the University of Manchester's Takedown Procedures [http://man.ac.uk/04Y6Bo] or contact uml.scholarlycommunications@manchester.ac.uk providing relevant details, so we can investigate your claim.

\section{OPEN ACCESS}




\section{JOURNAL OF ENGINEERING, DESIGN AND TECHNOLOGY DOI: 10.1108/JEDT-09-2020-0379}

\section{Building Information Modelling (BIM) Readiness of Construction Professionals: The Context of the Seychelles Construction Industry}

a Vincent Adam, ${ }^{b}$ Patrick Manu, a Abdul-Majeed Mahamadu, ${ }^{a}$ Krzysztof Dziekonski,

${ }^{c}$ Ernest Kissi, ${ }^{d}$ Fidelis Emuze, and a Simon Lee

${ }^{a}$ Department of Architecture and the Built Environment, University of the West of England, Bristol, BS16 1QY, United Kingdom.

${ }^{b}$ Department of Mechanical Aerospace and Civil Engineering, The University of Manchester, Manchester, M13 9PL, United Kingdom

${ }^{c}$ Department of Construction Technology and Management, Kwame Nkrumah University of Science and Technology, Kumasi, Ghana

${ }^{d}$ Department of Built Environment, Central University of Technology, Bloemfontein, South Africa

Corresponding author: Patrick Manu

Email: Patrick.Manu@manchester.ac.uk

Telephone: 00441613067572 


\begin{abstract}
Purpose: Whereas BIM adoption in developed countries has largely been incentivised by government, in developing countries, adoption is often driven by desires of industry professionals, which is dependent on awareness of BIM and availability of skills among the professionals. Thus BIM awareness and competence among professionals has become a useful baseline measure of BIM readiness. In order to ascertain BIM readiness within the Seychelles construction industry, this study investigated the level of BIM awareness and level of BIM competence among construction professionals.
\end{abstract}

Design/methodology/approach: The study involved a questionnaire survey of construction professionals $(n=96)$ and data analysis using both descriptive statistics and association analysis.

Findings: The results indicate a moderate level of BIM awareness, but a low level of engagement in BIM education/training. Also, the professionals have very low BIM technical skills, notably the ability to use BIM-related tools and to perform BIM-related task. Furthermore, the study suggests that the experience of working on collaborative projects could be a useful premise for BIM implementation among construction professionals.

Originality/value: The implication is that construction professionals in the Seychelles need to start readying themselves for greater BIM adoption by taking steps to address the BIM technical skills deficiencies and the low engagement in BIM education/training.

Keywords: association analysis; building information modelling; BIM; competence; developing countries; Seychelles.

\title{
INTRODUCTION
}

The Seychelles is a small country with a population estimated at 94,205 (National Bureau of Statistic, 2017). This indicates that its construction industry is very small compared to many other countries. Nevertheless, the construction industry is an important contributor to the Seychelles economy. The records from December 2016 showed that construction contributed $3.1 \%$ to gross domestic product (GPD) in 2015 (National Bureau of Statistic, 2016), and there is continuous improvement in the industry. The potential benefit of BIM in terms of promoting further improvement in Seychelles construction cannot be overemphasised. This is from the backdrop of gains made in other countries as a result of BIM adoption. However, in order for the Seychelles to make meaningful efforts towards BIM adoption there needs to be some readiness among the industry professionals (Succar et al., 2013).

Currently, there are many construction professionals working in the Seychelles, performing different roles. However, their level of BIM awareness and readiness is unknown. While several studies on BIM adoption have been undertaken in several countries, no study has been undertaken to explore the subject of BIM readiness 
among professionals in the Seychelles (see Rogers et al., 2015). In order to address this gap, this research, therefore, looked at the BIM readiness of construction professionals in Seychelles, particularly in terms of their BIM awareness and competence. The paper commences with a review of literature on BIM, covering its benefits, implementation challenges and competency requirements. The research design is then outlined followed by findings, discussion and conclusions.

\section{LITERATURE REVIEW}

The review of literature commences with an overview of BIM including its benefits and challenges and the review subsequently focuses on aspects of BIM relating to readiness.

\section{BIM Benefits and Challenges}

Succar (2009) defines BIM as "a set of interacting policies, processes and technologies generating a methodology to manage the essential building design and project data in digital format throughout the building's life-cycle". Generally, BIM is considered as a strong driver for new ideas, modernisation and productivity in the construction industry (Bui et al., 2016). The way that buildings are designed, constructed, operated and maintained has changed dramatically due to the rapid improvements in computerisation throughout the industry (Eastman, 2011). The aim of BIM is to provide efficiency in construction project processes and assist with better collaborative working (Holzer, 2011; Cabinet Office, 2011). A socio-technical system is another way to describe BIM, due to the involvement of technical aspect and automations, and the way that it drives the actors in the industry to re-think ways of going about the processes (Sackey et al., 2014).

The improved collaboration, that BIM presents, is related to the manner of integration of the different disciplines involved on a project (Emmitt, 2010). Consequently, BIM presents important benefits, such as allowing early detection of issues (e.g. errors in design, estimating, inconsistent transfer of information amongst the project stakeholders, and health and safety hazards (Zghari, 2013; Bryde at al., 2013; Martínez-Aires et al., 2018)) which can, therefore, be acted on early. However, because of early detection of errors and better flow of information, it is expected that with BIM implementation there will be significantly less revisions during construction. This will, therefore, influence further positive outcomes, such as ensuring cost certainty and early project completions (Migilinskas et al., 2013). These are two of the main concerns on construction projects (Prajapati et al., 2016). Avoidance of cost overrun on construction projects, and achieving cost savings when possible can be very beneficial for a country's economy (Cabinet Office, 2011; Sunday, 2010; Shete et al., 2016).

Despite the benefits that BIM can bring, it also has its challenges that can potentially delay or discourage some potential users. One common concern, that often arises, is the cost of BIM implementation (Navendren et al., 2014). Cost is mostly mentioned in two aspects. Firstly, there is the cost of education and training, which can be very high 
(Chan, 2014; Liu, et al., 2015). Then there is the need to acquire BIM specific software and equipment, which is also costly (Eadie et al., 2014; NBS, 2014; Allen Consulting Group, 2010). There is also uncertainty and confusion that arises regarding the identification of the roles and responsibilities of the different stakeholders (Holzer, 2007), as shown in a study in South Africa (Kekana et al., 2014). Another profound challenge regarding BIM readiness is the awareness and competencies among professionals (Succar et al., 2013). This is even more prevalent in developing country contexts where bottom-up approaches to adoption are more prevalent compared to other developed countries where there is higher government and client demand for BIM implementation (Kekana et al., 2014; Kassem and Succar, 2017). Thus BIM competence among construction professionals has been viewed as one of the baseline indicators of BIM readiness in countries (Succar, 2010; NBS, 2014)

\section{BIM Readiness: An Overview of Awareness and Competence}

BIM is most commonly implemented within organisations, and these organisations are in turn made up of teams of individuals (Rodgers et al., 2015). The individuals are the basic and most important components in the functionality and productivity of an organisation. For an organisation to achieve its optimum output, the individuals must be competent. They must have the necessary skills and knowledge in their work. The competence of individuals within an organisational setting is a fundamental block of an organisation's capability (Succar et al., 2013; Manu et al. 2019a). The UK Civil Service Human Resources (2015) states that, "competencies are the skills, knowledge and behaviours that lead to successful performance", while The BIM Framework Blog (2014) describes individual competence as the determination of an individual's ability to carry out an activity or task and deliver an outcome. It also further states that, "individual competency applies to a single person irrespective of role, position or employment status". This is similar to how individual BIM competency is interpreted by Succar et al (2013) who describe individual BIM competency as the personal traits, professional knowledge and technical abilities required by an individual to perform a BIM activity or deliver a BIM-related outcome. These abilities, activities or outcomes must be measurable against performance standards and can be acquired or improved through education, training and/or development. Individual BIM competency consists of the element of skill, the element of knowledge and the element of experience in BIM implementation (Succar et al., 2013).

\section{BIM Skills}

Davies et al (2015) put BIM skills into three categories. They are as follows:

- Technical skills: This is the ability to use BIM tools. It consists of attributes such as the ability to generate $3 \mathrm{D}$ models/animation using specialised computer software; management and maintenance of BIM models using official procedures that have been set down; storing, managing and sharing of files using a central data management and sharing system such as Autodesk A360; 
managing information technology (IT) systems; and others (Change Agents AEC, 2017). These are mostly skills that can be learned (Davies et al., 2015).

- Soft skills: This refers to an individual's personal quality to have effective interactions and good relationships with other people. Soft skills include attributes such as leadership, communication, time management, negotiation, expectations management, influencing, initiative, problem-solving, creativity, flexibility and decision-making. These skills are difficult to teach or to learn (Marando, 2012; Mordue et al., 2015; Davies et al., 2015).

- Discipline-specific skills: This is essential background knowledge of the construction industry before involving BIM. A professional aspiring to participate on BIM projects is expected to be well conversant or qualified in a discipline, for example be qualified as an architect, quantity surveyor, structural engineer, project manager, etc. This takes into account the technical complexity of BIM, therefore when discipline-specific skills are present this ensures that all the actors are already proficient in their discipline knowledge within the built environment. With this knowledge in place, facing BIM challenges becomes more feasible (Succar et al., 2013; Davies et al., 2015).

\section{BIM Knowledge and Awareness}

BIM knowledge is the state of having a good understanding of what BIM is as well as the related activities and tasks required to successfully use BIM (Succar, et al., 2013). Usually this is developed from receiving some education, training or through experience. Although BIM knowledge is considered difficult to measure, the NBS has operationalised this in their BIM readiness surveys through assessment of understanding of basic terms and concepts related to BIM (NBS, 2014). Furthermore several studies have taken this approach to assess readiness especially within developing countries (Rogers et al., 2015; Amuda et al., 2017; Amuda et al., 2018).

\section{BIM Experience}

BIM experience is the attributes gained through exposure to the BIM environment. It can be assessed by establishing the following (Succar et al., 2013):

- How long someone has been working in the BIM environment?

- What was their role?

- How many BIM projects one has worked on?

-What sizes of projects was worked on?

The more experienced someone is, the more smoothly it is expected that he/she will be able to deliver a desired outcome. Additionally, other team members with less or no experience can be guided by the more experienced member(s).

Given the fast pace of BIM implementation in several countries and its associated benefits, it is expected that with time there would be a growing demand for BIM implementation in the Seychelles construction industry. This would mean that the construction professionals would need to be ready to perform their functions on BIM 
enabled projects. The next section presents the research method applied to ascertain the BIM readiness of these professionals in the Seychelles construction industry, particularly focusing on BIM awareness, education/training and technical skills.

\section{Professionals engaging with BIM}

The construction industries around the world are recognising the benefits of BIM, and they are gradually adopting it in place of traditional project implementation methods. However, as previously mentioned, teams are made up of individuals, and individuals require competence to achieve the desired level of success. Therefore, it is essential for team members to evolve and adapt to the new methods and working environment that BIM presents.

Architectural firms are very important contributors in BIM projects. Consequently, architects are very active in BIM implementation (Gu et al., 2010). Generally, the main task of an architect working in a BIM project remains the same as that for an architect working in a traditional project. However, BIM presents a change in process. The 3D BIM model has a more important and central role in the lifecycle of the project than it used to have. Furthermore, there is sharing of information with other stakeholders via a central online system

The structural engineers' approach to BIM implementation is very similar to that of the architects. Looking further into the structural engineers' role in BIM projects; initially, they must analyse and understand the architectural drawings, just as they would normally do on a traditional project. This is to set the platform for the creation of the analytic model that will be later transferred into the 3D model (Hunt De Leon, 2004).

It has been observed that, for a while, the services engineers were being left behind regarding the application of BIM technologies. Software development for other disciplines, such as architects and structural engineers, have been moving much faster, as they have been the most active BIM disciplines from the start (Hunt, 2015). However, the situation has changed as software makers are making efforts to keep all the relevant disciplines up to date with the industry.

There are concerns about the long-term existence of the quantity surveying discipline, because of the emergence of BIM. This is mainly because cost estimates can be generated directly from the BIM models. However, opinions suggest that quantity surveyors should welcome BIM adoption with optimism. However, they must also be prepared to make the necessary changes to their usual way of working (BCIS, 2011).

Given the fast pace of BIM implementation in several countries and its associated benefits, it is expected that with time there would be a growing demand for BIM implementation in the Seychelles construction industry. This would mean that the above groups of professionals would need to be ready to perform their functions on BIM enabled projects. The next section presents the research method applied to ascertain the BIM readiness of these professionals in the Seychelles construction 
industry, particularly focusing on BIM awareness, education/training and technical skills.

\section{RESEARCH METHODOLOGY}

In order to obtain a generic view of the BIM awareness and competence of construction professionals in the Seychelles, a cross-sectional survey of construction professionals was adopted. This approach was adopted due to the suitability of quantitative surveys for ascertaining a generalised view of phenomena (Fellows and Liu, 2008; Creswell, 2009).

\section{Survey Design}

The survey approach was used to assess the BIM awareness, education/training and technical skills of the professionals. Additionally, the survey enabled exploration of any associations between BIM competencies possessed by professionals. An online questionnaire (hosted at Bristol Online Survey) was designed for the survey. The questionnaire was structured into two main parts as follows:

Part 1 - This captured respondents' demographic information including professional role, work experience, and information about their organisation.

Part 2 - This captured information about BIM awareness, BIM education/training, and level of ability in the use BIM-related tools and in performing BIM-related tasks (see Change Agents AEC, 2017; 2019). The level of ability was assessed on a five-point Likert scale (i.e. $1=$ none, $2=$ basic, $3=$ intermediate, 4 = advance, and 5 = expert).

For the survey administration, primarily, the professional consultancy practices in the Seychelles construction industry were targeted. A list containing 119 architectural firms, and 24 engineering (structural) firms was generated from the records of firms registered with The Seychelles Planning Authority. The list was supplemented by another list of 11 contractors, 2 project management consultancies, 3 mechanical, electrical and plumbing (MEP) engineering firms, and 6 quantity surveying firms compiled from contacts within the researchers' professional networks. The two lists were aggregated to form a single list of 165 firms. As previously mentioned, Seychelles is a small country with a population of about 94,000 , and therefore it is not surprising that the combined list resulted in a total number of 165 firms. Out of the 165 firms, email contacts were available for 149 firms (i.e. 90\%) which constituted the sampling frame for this study as the questionnaire was web-based and had to be administered electronically. A web link to the questionnaire (hosted at Bristol Online Survey) was included in an email to the 149 firms. The email requested for the participation of construction professionals (i.e. architects, structural engineers, services engineers, quantity surveyors, and project/construction managers) within the firms. Response rate in construction surveys is usually low (Xiao, 2002). Therefore, in order to help improve the responses, the email also contained a request for the prospective 
participants to forward the survey link to other construction professionals within their networks. This was to allow for snowballing. From the survey distribution a total of 96 responses were received and used in data analyses.

\section{Data Analyses}

Descriptive statistics (including frequency, mean and standard deviation) were used to present the results regarding the BIM awareness and education/training as well as the level of BIM competence of the respondents. Additionally, association analysis was applied to explore associations between respondents' characteristics as well as their BIM competence (Kotu and Deshpande, 2015). Association analysis measures the strength of co-occurrence between variables. The goal of association analysis is to find patterns in the co-occurrences of the variables and to find patterns in data in the form of rules (Kotu and Deshpande, 2015). The association analysis was conducted using the statistical data analysis software, Statistica version 13.

\section{FINDINGS}

The findings cover respondents' demographic information, BIM competence, and the outcome of the association analysis.

\section{Demographic Information}

Table 1 shows the demography of the respondents. The respondents are mainly architects (i.e. $49 \%$ ) and structural engineers (i.e. $29.2 \%$ ), with a majority of the respondents having more than 10 years of experience in their job function (i.e. 86.5\%) and in the Seychelles construction industry (i.e. 83.4\%). Respondents working in micro-medium size firms dominated the sample (i.e. $48 \%$ ) and the majority (i.e. $82.3 \%$ ) of respondents work for a private organisation.

\section{[Insert Table 1]}

\section{BIM Awareness, Education/Training and Ability in Using BIM-related Tools}

A majority of respondents (i.e. $60.4 \%$ ) indicated that they were aware of BIM prior to taking part in the survey. Regarding BIM education/training, $80 \%$ of the respondents indicated that they have not received any BIM education/training.

Table 2 shows the levels of proficiency of the respondents in relation to the use of BIM-related softwares. The overall mean ability of respondents in architecture function, MEP services engineering function, and quantity surveying function to use BIM tools related to their respective functions is $1.41,1.40$, and 1.04 respectively. When relating these overall mean scores to the five-point assessment scale, the mean scores approximate to 1 (i.e. NONE), which indicates that overall the respondents have a very low ability to use the BIM tools related to their respective functions. The 
overall mean ability of the respondents in structural engineering function to use the BIM-related structural engineering software is 1.50. This mean score approximates to 2 (i.e. BASIC) on the five-point assessment scale and this indicates that overall the respondents have a low ability to use those BIM-related structural engineering software.

Aside the assessment of BIM ability in relation to work function, the ability of all the respondents was assessed in relation to the use of BIM software for information/file sharing. In this regard, the overall mean ability of all the respondents is 1.09 , which approximates to 1 (i.e. NONE) on the five-point Likert scale, implying that generally, the respondents have a very low ability in the use of those BIM software for information/file sharing.

Being mindful that there may be other BIM-related software aside the more prominent ones that were assessed by the questionnaire, the respondents were asked to indicate other software they use in their work function. Out of the 96 respondents, 42 respondents (i.e. 43.8\%) provided responses which include: Autodesk AutoCAD, Google Sketchup, Win QS, Autodesk Quantity Take-off and Staad Pro. Autodesk AutoCAD was the predominant response.

[Insert Table 2]

\section{Ability to Perform BIM-related Task}

As previously indicated, the study also inquired into the ability of the respondents to perform several BIM-related tasks. In this regard respondents were asked whether they generate digital outputs in 3D as part of their role. Less than half of the respondents (i.e. 42.7\%) indicated that they do. Further assessment of the proficiency of the respondents in undertaking BIM-related task is shown below in Table 3.

From Table 3 the overall mean ability of the respondents to generate digital outputs in $3 \mathrm{D}$ is 2.53 which approximates to 3 (i.e. INTERMEDIATE) on the five-point scale, implying that overall the respondents have a moderate ability in performing this task. Respondents with job function as architecture have the highest mean ability (i.e. 3.00) to generate 3D output. Regarding the respondents' ability to manipulate 3D models, and their ability to use software tools and specialised equipment to capture and represent physical spaces and environments the overall mean scores are 1.38 and 1.34 respectively. Both score approximates to 1 (i.e. NONE) on the five-point scale, implying that overall the respondents have very low ability in performing these tasks.

Given that a key aspect of BIM implementation is collaboration (Eastman et al., 2011; Mahamadu et al, 2018), abilities relating to general information technology (IT) management and collaboration in a BIM environment were also investigated. In this regard, respondents were asked whether they have experienced working on a collaborative project that involved early engagement of key stakeholders (e.g. 
architect, engineers, cost consultant and contractor) to contribute their expertise and knowledge. Less than half of the respondents (i.e. 42.7\%) indicated that they have such experience. However, the vast majority of respondents (i.e. 83.3\%) perceive that they can work on such collaborative project. Further assessment of the proficiency of the respondents regarding general IT management and collaboration in a BIM environment is shown below in Table 4. Overall, the table shows a very low to low ability.

[Insert Table 3]

[Insert Table 4]

\section{Association Analysis}

As previously mentioned, association analysis was applied to explore associations between respondents' characteristics as well as their BIM competence (Kotu and Deshpande, 2015). According to Kotu and Deshpande, (2015), basic association analysis shows the co-occurrence of variables in a dataset. The outcome of an association analysis can be shown as a set of association rules $\{A\}->\{B\}$. A rule indicates that if variable $A$ has been found in a dataset's record, there is great probability of occurrence of variable $B$ within the same record. The strength of a rule is measured by the support and confidence of a rule.

The support of rule is the relative frequency of occurrence of a variable in the dataset. It measures how all the items in a rule are represented in overall dataset. Since the support indicates variables with high occurrence, it uncovers the patterns in a dataset that should be investigated. It indicates whether a rule is worth considering. Association rules with low support have either infrequently occurring items or an item relationship occurs just by chance, which may yield spurious rules (Tan et al., 2004). The confidence of a rule measures the likelihood of occurrence of the consequent of the rule out of all the records that contain the antecedent of the rule. Confidence provides the reliability measure of the rule. Additionally, a lift of the rule needs consideration. Lift is the ratio of the observed support of variables in the rule with what is expected if variables usage was independent. Lift values closer to 1 mean the antecedent and consequent of the rule are independent. The higher the value of lift, the more interesting the rules are (Kotu and Deshpande, 2015). Lift values greater than 1 indicate that the occurrence of the rule antecedent has a positive effect on the occurrence of the rule consequent. In the same way, lift values smaller than 1 indicates that the occurrence of the rule antecedent has a negative effect on the occurrence of the rule consequent.

The results of association analysis are presented on the rule graph in Figure 1. Node size represents relative support of variables (antecedent and consequence), while its colour represent the relative confidence. For the sake of brevity, only rules with at least 
$25 \%$ confidence are shown. The results presented in Figure 1 suggests that there is a close relationship between respondents' perceived ability to work on a collaborative project that involves early engagement of key stakeholders (i.e. "collaborative project ability" in Figure 1) and their BIM awareness. Respondents who perceived to be able to work on a collaborative project, as a consequence were BIM aware. However, as indicated by node colour darkness, it is the BIM awareness leading to perceived ability to work on a collaborative project rule that reveals higher confidence.

Detailed results of the association analysis are presented in Table 5. The table highlights association rules with support greater than $35 \%$. Results presented in the table indicate a clear relationship between BIM awareness and respondents' perceived ability to work on a collaborative project. Those two variables are the most frequent consequent of the association rules. Also, respondents' perceived ability to work on a collaborative project as well as their experience of working on a collaborative project (i.e. "collaborative project participation" in Table 5) are the most frequent antecedent of the association rules. To further explore the relationship between the most frequent antecedents and consequents in the association rules, a casual loop diagram has been created (see Figure 2). On each rule arrow, the confidence and lift (in brackets) have been shown.

The rules' dynamics shown in Figure 2 indicate that the highest support (56.25\%) was given to two rules: BIM awareness - > Collaborative project ability (i.e. ability to work on a collaborative project); and Collaborative project ability - > BIM awareness. However, a higher confidence $(93.10 \%)$ was revealed for BIM awareness being antecedent to respondents' perceived ability to work on a collaborative project. Figure 2 also indicates that respondents' experience of working on a collaborative project affects their BIM awareness as shown by the rule, Collaborative project participation (i.e. experience of working on a collaborative project) - > BIM awareness $(36.45 \%$ support with $85.36 \%$ confidence). The results, therefore, suggest that the ability to work on a collaborative project and the experience of working on a collaborative project positively affects the awareness of BIM. Conversely, there is a (higher) probability that professionals who are BIM aware would also be able to work on a collaborative project. Figure 2 also shows another feedback loop for the two rules: Collaborative project participation - > Collaborative project ability; and Collaborative project ability - > Collaborative project participation. However, a higher confidence $(97.56 \%)$ was revealed for collaborative project participation being antecedent to collaborative project ability. The results thus suggests that there is a higher likelihood for professionals who have experience of working on a collaborative project to be able to work on a collaborative project. Overall, considering the feedback loops shown by Figure 2 together with the confidence and lift values shown by Table 5, it emerges that Collaborative project participation is the most relevant path for developing BIM awareness as well as Collaborative project ability. 
[Insert Table 5]

[Insert Figure 2]

\section{DISCUSSION}

An individual's readiness to implement BIM can be ascertained by assessing the BIM competency of that individual. In this research, the BIM competency of construction professionals in the Seychelles was primarily assessed with reference to their BIM awareness, ability to use BIM software and to perform BIM-related tasks (Succar et al., 2013). The research also sought to gauge the engagement in BIM education/training by the construction professionals given that it facilitates the development of BIM competence.

Regarding BIM awareness and education/training, the findings revealed moderate awareness (i.e. $60 \%$ of the respondents being aware of BIM), but low engagement in BIM education/training. This shows that although the professionals may be aware of the potential impact of BIM in the transformation of the built environment, such awareness has not necessarily triggered action among the professionals to acquire more knowledge and understanding of BIM in order to enhance their readiness to implement BIM. The findings of the study is similar to reports on BIM uptake in several developing countries (Ismail et al., 2017). A literature review by Ismail et al. (2017) on BIM uptake in several developing countries in Asia revealed that BIM knowledge and education pose a challenge to BIM uptake, despite a high awareness of BIM in some countries. A BIM survey in Brunei also revealed that while $60 \%$ of the respondents ( $\mathrm{n}$ = 90) were aware of BIM, less than $40 \%$ attended any talks on BIM (Rahman, 2017), thus suggesting low engagement in BIM professional development training.

Comparing BIM (as a new and burgeoning way of working in construction) to other new and growing approaches in construction to improve performance (e.g. design for safety (DfS)) the findings of this study are very much in sync with findings that have been reported from other developing countries in sub-Saharan Africa (Manu et al., 2018, 2019b). Manu et al. (2018, 2019b), through surveys in Ghana and Nigeria regarding DfS implementation, awareness and education/training, revealed that while a vast majority (i.e. over $85 \%$ ) of the survey participants (i.e. architects) are aware of DfS, fewer (i.e. less $40 \%$ ) engage in DfS professional development training.

Regarding technical BIM skills, the findings show that while there are several BIM software already in use in the Seychelles, the level of ability in the use of the BIM software related to the disciplines investigated (i.e. architecture, structural engineering, services engineering and quantity surveying) is generally low. A similar trend is noticed for the ability of the professionals to perform BIM-related task. Altogether, these findings thus reveal a low level of ability among the construction professionals in the use of BIM tools and the performance of BIM-related task. This 
outcome, when juxtaposed against the level of awareness of BIM among the professionals shows that the BIM awareness does not necessarily result in higher levels of proficiency in using BIM tools and performing BIM-related tasks. Again this outcome is similar to reports from other developing countries which show a low level of BIM implementation in spite of high awareness (Ismail et al., 2017; Amuda et al., 2018). For instance, a survey on the status of BIM in India involving 365 professionals revealed that while $92 \%$ of the respondents are aware of BIM less than $25 \%$ are using BIM (Sawhney et al., 2014). Once again, parallels can be drawn from the outcomes of this study and the outcomes of studies regarding the actual implementation of other burgeoning construction approaches in developing countries (e.g. DfS). In this vein, Manu et al. $(2018,2019 b)$ reported that the high level of awareness of DfS in Ghana and Nigeria was out of sync with a rather low level of implementing DfS practices among architects.

Altogether, the results of this study show that efforts are needed in order to enhance BIM education/training and actual BIM implementation in terms of the technical skills of professionals in the Seychelles. Such efforts would have to address any BIM implementation barriers/challenges responsible for the imbalance between awareness, education/training, and the ability to use BIM tool and to perform BIM tasks. While this study does not offer insights regarding what such barriers/challenges might be, the body of research evidence on BIM implementation in developing countries suggests that the barriers at play in Seychelles could include: mind-set issues among industry stakeholders; lack/inadequate coverage of BIM in the education of construction professionals; lack/inadequate BIM professional development training; lack of government leadership; and costs relating to BIM knowledge acquisition and implementation (Ismail et al., 2017). These potential barriers are multi-level/faceted in nature (i.e. relate to the individual professional (individual level), the professional's organisation/employer (organisational level), and the wider industry/national environment and thus indicates the need for concerted, multi-pronged and joined-up approaches by industry stakeholders to address such challenges.

Based on the association analysis, the relationship between BIM awareness and BIMrelated competency was revealed. The study showed positive relationships between BIM awareness, the ability to work on a collaborative project, and experience of working on a collaborative project. However, experience of working on a collaborative project has the most influence on BIM awareness and the ability to work on a collaborative project. Thus experience of working collaboratively on a project is a good premise for BIM implementation, given that BIM implementation is a collaborative way of working (Eastman et al., 2011; Mahamadu et al, 2018).

\section{CONCLUSION}


While there is yet to be a surge in BIM implementation in the Seychelles, this research has shown that there is a fair level of awareness among professionals. Although several professionals are aware of BIM, there are few who have undergone BIM education/training. Furthermore, professionals generally have low levels of proficiency in the actual use of BIM-related software and the performance of BIM-related tasks. Thus there is a mismatch between: (1) the level of BIM awareness; and (2) the level of engagement in BIM education/training; and (3) the level of proficiency of technical BIM skills of professionals. However, the study revealed strong associations between experience of working on a collaborative project, BIM awareness and ability to work on a collaborative project. The associations suggest that professionals having the experience of working on collaborative projects could be a useful premise for BIM implementation amongst construction professionals in the Seychelles. Given the benefits of BIM and its growing prominence in many countries (both developed and developing) it would be useful for Seychelles construction professionals and the wider body of stakeholders to start readying themselves for greater BIM adoption in the construction sector. While this would involve taking steps to address the BIM technical skill deficiencies and the low engagement in BIM education/training highlighted by this study, it should also consider broader BIM implementation issues that have been noted in other developing countries in order to develop a joined-up national/industrywide BIM implementation roadmap or strategy.

\section{Limitations and further research}

This study has some limitations which are highlighted below:

- The growth of BIM implementation in construction has yielded the proliferation of several BIM-related software tools and the introduction of several BIM competency items (see Change Agents AEC, 2017; 2019) all of which could not be explored in this study. While the outcomes of this study provide important insights into BIM readiness in the Seychelles construction industry, further readiness assessment studies are encouraged in order to explore proficiency in other BIM tools and competency items not included in this study.

- Additionally, this study focused only on professionals and thus other studies can focus on organisational BIM implementation capacity/readiness in the Seychelles.

- Furthermore, while this study has showed inadequate bottom-up (professionals led) BIM promotion, there is a need to explore how top-down (government-led) promotion might incentivise BIM adoption.

\section{REFERENCES}

Allen Consulting Group (2010), "Productivity in the buildings network: assessing the impacts of Building Information Models: report to the Built Environment 
Innovation and Industry Council”, Allen Consulting Group, Sydney. Available from:

http://www.acilallen.com.au/cms_files/acgbuildingsproductivity2010.pdf [Accessed 23 July 2017].

Amuda G.Y., Adebiyi R.T. and Muhammad, I.B. (2018), "BIM awareness and adoption by construction organizations in Nigerian", Journal of Research Information in Civil Engineering, Vol. 15, No. 2, pp. 2205- 2224.

Amuda, G.Y, Adebiyi, R. T., Olowa, T. O. O. and Oladapo, I. B. (2017), "Barriers to building information modelling adoption in Nigeria", Journal of Research Information in Civil Engineering, Vol. 14, No. 2, pp.1478-1495.

BCIS (2011), RICS 2011 building information modelling survey report, BCIS London.

Bryde, D, Broquetas, M. and Volm, J.M. (2013), "The Project Benefits of Building Information Modelling (BIM)", International Journal of Project Management. Vol. 31, pp. 971-980.

Bui, N., Merschbrock, C., Munkvold, B. (2016), "A review of building information modelling for construction in developing countries", Procedia Engineering. Vol. 116 , pp. 487- 494.

Cabinet Office (2011), "Government Construction Strategy". London: HMSO. Available from: https://www.gov.uk/government/uploads/system/uploads/attachment_data/file/6 1152/Govern ment-Construction-Strategy_0.pdf [Accessed 27 June 2017].

Chan, C.T.W. (2014), "Barriers of implementing BIM in construction industry from the designers' perspective: A Hong Kong experience", Journal of System and Management Sciences, Vol. 4 (2), pp. 24-40.

Change Agents AEC (2017), "BIMe Initiative Individual Discovery", Available from: http://bimexcellence.com/assess/campaign/default/ [Accessed 20 May 2017]

Change Agents AEC (2019), "BIMe Initiative 201 in Competency Table v2.1", Available from: https://bimexcellence.org/resources/200series/201in/ [Accessed 11 September 2019]

Civil Service Human Resources (2015), "Civil Service Competency Framework 20122017". London: Civil Service Human Resources. Available from: https://assets.publishing.service.gov.uk/government/uploads/system/uploads/at tachment_data/file/500767/Civil_Service_Competency_Framework.pdf [Accessed 03 April 2017]

Creswell, J.W. (2009), Research design: qualitative, quantitative, and mixed method approaches, 3rd edn., Sage Publications, California.

Davies, K., McMeel, D. and Wilkinson, S. (2015), "Soft skills requirements in a BIM project team", In: Proceedings of the 32nd International Conference of CIB W78, Eindhoven, The Netherlands, 27-29 October, pp.108-117.

Eadie, R., Heanen, A. and Hall, J. (2014), "Civil engineering and the interoperability between building information modelling (BIM) and e-procurement", In: 
International Conference on Civil Engineering Design and Construction (Science and Practice), 11-13 September 2014, Varna, Bulgaria, pp. 59-65.

Eastman, C. (2011), BIM handbook: A guide to building information modeling for owners, managers, designers, engineers and contractors, 2nd edn, Wiley, Hoboken (NJ).

Emmitt, S. (2010), Managing Interdisciplinary Projects: A Primer for Architecture, Engineering, and Construction, Spon Press, London.

Fellows, R. and Liu, A. (2008), Research methods for construction, Blackwell Publishing, West Sussex.

Gu, N. and London, K. (2010), "Understanding and facilitating BIM adoption in the AEC Industry. Automation in Construction", Vol. 19, No. 8, pp. 988-999.

Holzer, D. (2007), "Are you talking to me? Why BIM alone is not the answer?" In: Proceedings of AASA 2007, Sydney, Australia.

Hunt De Leon, C.A. (2004), "The benefits of using building information modeling in structural engineering", MSc dissertation, Utah State University.

Hunt, S. (2015), "Why is the building-services sector lagging behind in BIM?" Available from:

http://www.modbs.co.uk/news/archivestory.php/aid/14890/Why_is_the_building - services_sector_lagging_behind_in_BIM_.html [Accessed 25 August 2017].

Holzer, D. (2011), "BIM's seven deadly sins", International Journal of Architectural Computing, Vol. 9, No. 4, pp. 463-480.

Ismail, N. A. A., Chiozzi, M. and Drogemuller, R. (2017), "An overview of BIM uptake in Asian developing countries", In AIP Conference Proceedings 1903, 080008, DOI: 10.1063/1.5011596.

Kassem, M., and Succar, B. (2017), "Macro BIM adoption: Comparative market analysis", Automation in Construction, Vol. 81, pp. 286-299.

Kekana, T.G., Aigbavboa, C.O. and Thwala, W.D. (2014), "Building Information Modelling (BIM): Barriers in Adoption and Implementation Strategies in the South Africa Construction Industry", In: International Conference on Emerging Trends in Computer and Image Processing (ICETCIP'2014). Pattaya, 15 December 2014. pp. 109- 111.

Kotu, V. and Deshpande, B. (2015), Predictive Analytics and Data Mining, Morgan Kaufmann, Boston.

Liu, S., Xie, B., Tivendal, L. and Liu, C. (2015) Critical barriers to BIM implementation in the AEC industry, International Journal of Marketing Studies, Vol. 7, No. 6, pp.162-171.

Mahamadu, A-M., Mahdjoubi, L., Booth, C., Manu, P., and Manu, E. (2019), "Building Information Modelling (BIM) capability and delivery success on construction projects", Construction Innovation: Information Process Management, Vol. 19, No. 2, pp. 170-192.

Manu, P., Poghosyan, A., Agyei, G., Mahamadu, A. M., and Dziekonski, K. (2018), "Design for safety in construction in sub-Saharan Africa: a study of architects in Ghana", International Journal of Construction Management. DOI: 10.1080/15623599.2018.1541704. 
Manu, P., Poghosyan, A., Mahamadu, A-M., Mahdjoubi, L., Gibb, A., Behm, M., and Akinade, O. (2019a), "Design for Occupational Safety and Health: Key Attributes for Organisational Capability", Engineering Construction and Architectural Management. DOI: 10.1108/ECAM-09-2018-0389

Manu, P., Poghosyan, A., Mshelia, I. M., Iwo, S. T., Mahamadu, A. M., and Dziekonski, K. (2019b), "Design for occupational safety and health of workers in construction in developing countries: a study of architects in Nigeria", International Journal of Occupational Safety and Ergonomics, Vol. 25, No. 1, pp. 99-109.

Marando, A. (2012), Balancing project management hard skills and soft skills, Rabb School of Continuing Studies Division of Graduate Professional Studies, Brandeis University, Massachusetts.

Martínez-Aires, M. D., López-Alonso, M. and Martínez-Rojas, M. (2018), "Building information modeling and safety management: A systematic review", Safety Science, Vol. 101, pp. 11-18.

Migilinskas, D., Popov, V., Juocevicius, V. and Ustinovichius, L. (2013), "The benefits, obstacles and problems of practical BIM implementation", Procedia Engineering, Vol. 57, pp. 767-774.

Mordue, S., Swaddle, P. and Philp, D. (2015), Building information modeling for dummies, John Wiley \& Sons, Chichester.

National Bureau of Statistics (2016), "Statistical Bulletin", Available from:

http://www.nbs.gov.sc/download-archive/resources/uploads/2016/12/ANA2015.pdf [Accessed 05 June 2017].

National Bureau of Statistics (2017), "Statistical Bulletin", Available from: http://www.nbs.gov.sc/downloads/data-acquisition-census/population-and-vitalstatistics/2017 [Accessed 05 June 2017].

Navendren, D., Manu, P., Shelbourn, M. and Mahamadu, A.-M. (2014), "Challenges to building information modelling implementation in UK: designers' perspectives", In Raiden, A. and Aboagye-Nimo, E. (Eds.), Proceedings 30th Annual ARCOM Conference, 1-3 September 2014, Portsmouth, UK. Association of Researchers in Construction Management.

NBS (2014), NBS National BIM Report 2014, NBS, Newcastle.

Prajapati, S.K., Gupta, R. and Pandey, M. (2016), "Causes and Effects of Cost Overrun on Construction Projects in Madhya Pradesh", International Journal of Engineering Development and Research, Vol. 4, No. 2, pp. 1346-1350.

Rahman, M. M. (2017) "Awareness of BIM adoption in Brunei", In AIP Conference Proceedings 1887, 020032. DOI: 10.1063/1.5003515.

Rogers, J., Chong, H.-Y. and Preece, C. (2015), "Adoption of building information modeling technology (BIM): Perspectives from Malaysian engineering consulting services firms", Engineering, Construction, and Architectural management, Vol. 22, No. 4, pp. 424-445.

Sackey, E., Tuuli, M. and Dainty, A. (2015), "Sociotechnical Systems Approach to BIM implementation in a Multidisciplinary Construction Context", Journal of Management in Engineering, Vol 31, No. 1, pp. 1-11. 
Sawhney, A., Kapoor, A., Kamthan, S., Agarwal, N., Bhakre, P. and S. Jain (2014), "State of BIM Adoption and outlook in India", Mumbai, RICS School of Built Environment, Amity University. Available at http://www.fig.net/resources/proceedings/fig_proceedings/fig2014/ppt/ss36/ss3 6_kavanagh_7434.pdf [Accessed 24 February 2019]

Shete, A.N. and Kothawade, V.D. (2016), "An Analysis of Cost Overruns and Time Overruns of Construction Projects in India", International Journal of Engineering Trends and Technology, Vol. 41, No. 1, pp. 33-36.

Succar, B. (2009), "Building information modelling framework: a research and delivery foundation for industry stakeholders", Automation in Construction, Vol. 18, No. 3, pp. 357-375.

Succar, B. (2010), "Building information modelling maturity matrix", In: Underwood, J. and Isikdag, $U$ (eds.) Handbook of Research on Building Information Modeling and Construction Informatics: Concepts and Technologies, Information Science Reference, Hersey (PA), pp. 65-103.

Succar, B., Sher, W. and Williams, A. (2013), "An integrated approach to BIM competency assessment, acquisition and application", Automation in Construction, Vol. 35, p. 174-189.

Sunday, O.A. (2010), "Impact of variation orders on public construction projects", In: Egbu, C., (eds.), Proceedings 26th Annual ARCOM Conference, 6-8 September 2010, Leeds, UK, Association of Researchers in Construction Management..

Tan, P., Kumar, V. and Srivastava, J. (2004), "Selecting the right objective measure for association analysis", Information Systems, Vol. 29, No. 4, pp.293-313.

The BIM Framework Blog (2014), "Competency", Available from: http://www.bimframework.info/competency/ [Accessed 29 March 2017].

Xiao, H. (2002), "A comparative study of contractor performance based on Japanese, UK and US construction practice", PhD Thesis, University of Wolverhampton.

Zghari, A. (2013), "The cost saving benefits of BIM", NBS. Available from: https://www.thenbs.com/knowledge/the-cost-saving-benefits-of-bim [Accessed 29 March 2017]. 




Figure 1: Association analysis rule graph 


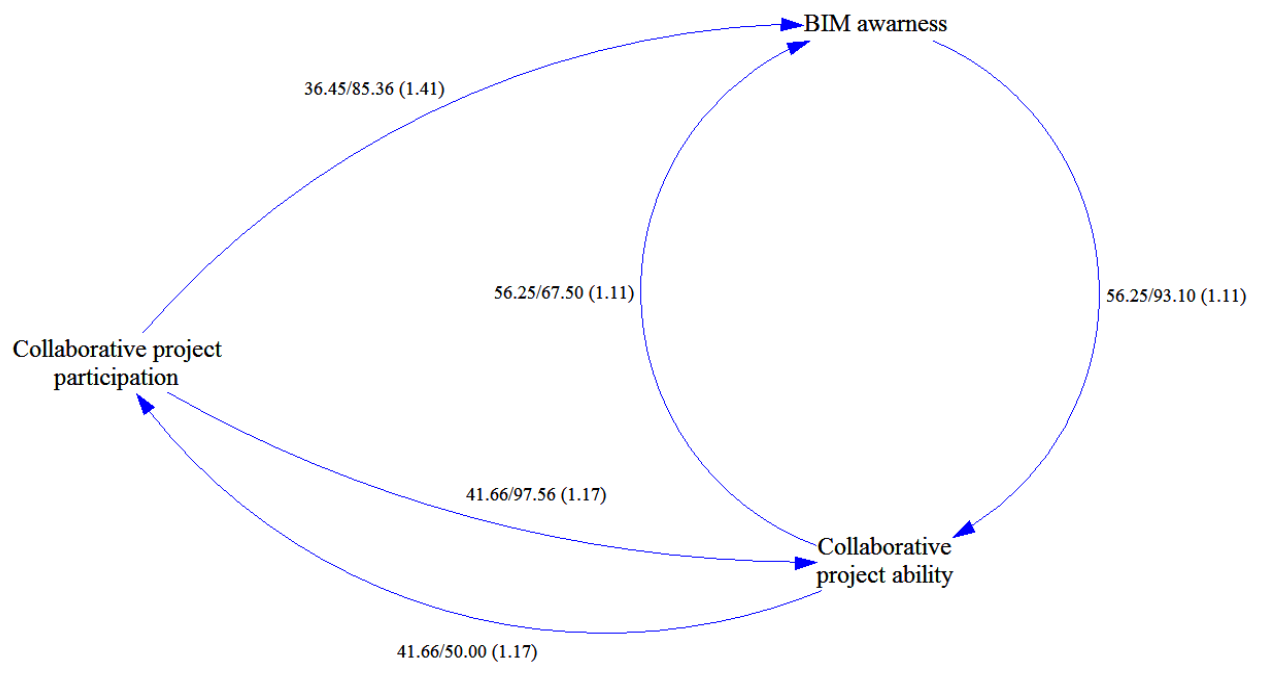

Figure 2: Association analysis rules' dynamics 
Table 1: Respondents' information ( $n=96)$

\begin{tabular}{|c|c|c|}
\hline Characteristics & Frequency & Percentage \\
\hline \multicolumn{3}{|l|}{ Job function ${ }^{a}$} \\
\hline Architecture & 47 & 49.0 \\
\hline Structural engineering & 28 & 29.2 \\
\hline Quantity surveying & 17 & 17.7 \\
\hline MEP engineering & 2 & 2.1 \\
\hline Project/construction management & 20 & 20.8 \\
\hline \multicolumn{3}{|l|}{ Years of experience in job function } \\
\hline $1-3$ years & 2 & 2.1 \\
\hline $4-6$ years & 4 & 4.2 \\
\hline $7-9$ years & 7 & 7.3 \\
\hline $10-12$ years & 23 & 24.0 \\
\hline $13-15$ years & 23 & 24.0 \\
\hline More than 15 years & 37 & 38.5 \\
\hline \multicolumn{3}{|c|}{ Years of experience in Seychelles construction industry } \\
\hline $1-3$ years & 3 & 3.1 \\
\hline $4-6$ years & 6 & 6.3 \\
\hline $7-9$ years & 7 & 7.3 \\
\hline $10-12$ years & 23 & 24.0 \\
\hline $13-15$ years & 22 & 22.9 \\
\hline More than 15 years & 35 & 36.5 \\
\hline \multicolumn{3}{|l|}{ Work condition } \\
\hline Working for a public organization & 17 & 17.7 \\
\hline Working for a private organization & 45 & 46.9 \\
\hline Self-employed & 34 & 35.4 \\
\hline \multicolumn{3}{|c|}{ Size of organisation by number of employees } \\
\hline 0-10 Employees (Micro firm) & 16 & 16.7 \\
\hline 11-49 Employees (Small firm) & 18 & 18.8 \\
\hline 50-249 Employees (Medium firm) & 12 & 12.5 \\
\hline Over 249 (Large firm) & 18 & 18.8 \\
\hline Non-response & 32 & 33.3 \\
\hline
\end{tabular}


Table 2: Ability to use BIM software

\begin{tabular}{|c|c|c|c|c|c|c|c|c|}
\hline \multirow[t]{2}{*}{ BIM software } & \multicolumn{6}{|c|}{ Ability } & \multirow{2}{*}{$\begin{array}{l}\text { Overall } \\
\text { mean }\end{array}$} & \multirow{2}{*}{$\begin{array}{l}\text { Std. } \\
\text { Dev. }\end{array}$} \\
\hline & None & Basic & Intermediate & Advanced & Expert & Mean & & \\
\hline \multicolumn{9}{|l|}{ Architecture } \\
\hline $\begin{array}{l}\text { Autodesk Revit } \\
\text { Architecture }\end{array}$ & 16 & 12 & 11 & 8 & 0 & 2.23 & \multirow{10}{*}{1.41} & \multirow{10}{*}{0.606} \\
\hline Graph iSOFT ArchiCAD & 10 & 7 & 14 & 14 & 2 & 2.81 & & \\
\hline $\begin{array}{l}\text { Nemetschek Allplan } \\
\text { Architecture }\end{array}$ & 36 & 11 & 0 & 0 & 0 & 1.23 & & \\
\hline $\begin{array}{l}\text { Gehry Technologies - } \\
\text { Digital Project Designer }\end{array}$ & 39 & 8 & 0 & 0 & 0 & 1.17 & & \\
\hline $\begin{array}{l}\text { Nemetschek Vectorworks } \\
\text { Architect }\end{array}$ & 38 & 8 & 1 & 0 & 0 & 1.21 & & \\
\hline Bentley Architecture & 36 & 10 & 1 & 0 & 0 & 1.26 & & \\
\hline $\begin{array}{l}\text { 4MSA IDEA Architectural } \\
\text { Design (IntelliCAD) }\end{array}$ & 44 & 3 & 0 & 0 & 0 & 1.06 & & \\
\hline CADSoft Envisioneer & 42 & 5 & 0 & 0 & 0 & 1.11 & & \\
\hline Softtech Spirit & 46 & 1 & 0 & 0 & 0 & 1.02 & & \\
\hline RhinoBIM (BETA) & 46 & 1 & 0 & 0 & 0 & 1.02 & & \\
\hline \multicolumn{9}{|l|}{ Structural engineering } \\
\hline Autodesk Revit Structure & 1 & 1 & 4 & 19 & 3 & 3.79 & \multirow{10}{*}{1.5} & \multirow{10}{*}{0.841} \\
\hline $\begin{array}{l}\text { Bentley Structural } \\
\text { Modeler }\end{array}$ & 15 & 9 & 1 & 2 & 1 & 1.75 & & \\
\hline $\begin{array}{l}\text { Bentley RAM, STAAD } \\
\text { and ProSteel }\end{array}$ & 21 & 4 & 2 & 0 & 1 & 1.43 & & \\
\hline Tekla Structures & 18 & 7 & 3 & 0 & 0 & 1.46 & & \\
\hline CypeCAD & 25 & 3 & 0 & 0 & 0 & 1.11 & & \\
\hline Graytec Advance Design & 27 & 1 & 0 & 0 & 0 & 1.04 & & \\
\hline $\begin{array}{l}\text { StructureSoft Metal } \\
\text { Wood Framer }\end{array}$ & 26 & 2 & 0 & 0 & 0 & 1.07 & & \\
\hline Nemetschek Scia & 28 & 0 & 0 & 0 & 0 & 1 & & \\
\hline 4MSA Strad and Steel & 28 & 0 & 0 & 0 & 0 & 1 & & \\
\hline $\begin{array}{l}\text { Autodesk Robot } \\
\text { Structural Analysis }\end{array}$ & 19 & 7 & 2 & 0 & 0 & 1.39 & & \\
\hline \multicolumn{9}{|l|}{ MEP services engineering } \\
\hline Autodesk Revit MEP & 1 & 0 & 0 & 1 & 0 & 2.5 & \multirow{5}{*}{1.4} & \multirow{5}{*}{0.652} \\
\hline $\begin{array}{l}\text { Bentley Hevacomp } \\
\text { Mechanical Designer }\end{array}$ & 1 & 1 & 0 & 0 & 0 & 1.5 & & \\
\hline $\begin{array}{l}\text { 4MSA FineHVAC + } \\
\text { FineLIFT + FineELEC + } \\
\text { FineSANI }\end{array}$ & 2 & 0 & 0 & 0 & 0 & 1 & & \\
\hline $\begin{array}{l}\text { Gehry Technologies - } \\
\text { Digital Project MEP } \\
\text { Systems Routing }\end{array}$ & 2 & 0 & 0 & 0 & 0 & 1 & & \\
\hline $\begin{array}{l}\text { CADMEP (CADduct / } \\
\text { CADmech) }\end{array}$ & 2 & 0 & 0 & 0 & 0 & 1 & & \\
\hline \multicolumn{9}{|l|}{ Quantity surveying } \\
\hline $\begin{array}{l}\text { Construction (Simulation, } \\
\text { Estimating and Const. }\end{array}$ & 12 & 3 & 2 & 0 & 0 & 1.41 & \multirow{3}{*}{1.04} & \multirow{3}{*}{0.13} \\
\hline $\begin{array}{l}\text { Analysis) } \\
\text { Autodesk Navisworks }\end{array}$ & 17 & 0 & 0 & 0 & 0 & 1 & & \\
\hline Solibri Model Checker & 17 & 0 & 0 & 0 & 0 & 1 & & \\
\hline
\end{tabular}




\begin{tabular}{l|l|l|l|l|l|l|l|l} 
Vico Office Suite & 17 & 0 & 0 & 0 & 0 & 1 & & \\
Vela Field BIM & 17 & 0 & 0 & 0 & 0 & 1 & & \\
Bentley ConstrucSim & 17 & 0 & 0 & 0 & 0 & 1 & & \\
Tekla BIMSight & 17 & 0 & 0 & 0 & 0 & 1 & & \\
Glue (by Horizontal & 17 & 0 & 0 & 0 & 0 & 1 & & \\
Systems) & 17 & 0 & 0 & 0 & 0 & 1 & & \\
Synchro Professional & 17 & 0 & 0 & 0 & 0 & 1 & & \\
Innovaya & 76 & 10 & 9 & 1 & 0 & 1.32 & & \\
\hline File sharing & 94 & 2 & 0 & 0 & 0 & 1.02 & & \\
Autodesk A360 & 95 & 1 & 0 & 0 & 0 & 1.01 & 1.09 & 0.134 \\
Revizto & 93 & 1 & 2 & 0 & 0 & 1.05 & & \\
Asite & 94 & 2 & 0 & 0 & 0 & 1.02 & & \\
BIMstorm & 4Site
\end{tabular}


Table 3: Ability to perform BIM-related tasks

\begin{tabular}{|c|c|c|c|c|c|c|c|c|}
\hline Ability & None & Basic & Intermediate & Advanced & Expert & Total & Mean & $\begin{array}{l}\text { Std. } \\
\text { Deviation }\end{array}$ \\
\hline \multicolumn{9}{|c|}{ Ability to generate digital outputs in 3D } \\
\hline $\begin{array}{l}\text { Frequency } \\
\text { Percent }\end{array}$ & 21 & 28 & 27 & $\begin{array}{c}15 \\
15.6\end{array}$ & 5 & $\begin{array}{c}96 \\
100.0\end{array}$ & 2.53 & 1.151 \\
\hline \multicolumn{9}{|c|}{ Ability to further manipulate 3D models } \\
\hline $\begin{array}{l}\text { Frequency } \\
\text { Percent }\end{array}$ & 70.8 & $\begin{array}{c}22 \\
22.9\end{array}$ & $\begin{array}{c}4 \\
4.2\end{array}$ & $\begin{array}{c}2 \\
2.1\end{array}$ & $\begin{array}{c}96 \\
100.0\end{array}$ & $\begin{array}{c}68 \\
70.8\end{array}$ & 1.38 & 0.669 \\
\hline \multicolumn{9}{|c|}{$\begin{array}{l}\text { Ability to use software tools and specialised equipment to capture and represent physical spaces and } \\
\text { environments. }\end{array}$} \\
\hline $\begin{array}{l}\text { Frequency } \\
\text { Percent }\end{array}$ & 74.0 & 21.9 & 1.0 & 2.1 & 1 & $\begin{array}{c}96 \\
100.0\end{array}$ & 1.34 & 0.708 \\
\hline
\end{tabular}


Table 4: General IT management and collaboration ability

\begin{tabular}{|c|c|c|c|c|c|c|c|c|}
\hline Ability & None & Basic & Intermediate & Advanced & Expert & Total & Mean & $\begin{array}{c}\text { Std. } \\
\text { Deviation }\end{array}$ \\
\hline \multicolumn{9}{|c|}{ Ability to install, manage and maintain general IT systems (e.g. networks and data storage systems) } \\
\hline Frequency & 25 & 55 & 13 & 2 & 1 & 96 & & \\
\hline Percent & 26.0 & 57.3 & 13.5 & 2.1 & 1.0 & 100.0 & 1.95 & 0.759 \\
\hline \multicolumn{9}{|c|}{ Ability to receive, manage or share information with others in a central online database } \\
\hline Frequency & 74 & 15 & 6 & 1 & 0 & 96 & & \\
\hline Percent & 77 & 16 & 6 & 1 & 0 & 100 & 1.31 & 0.638 \\
\hline \multicolumn{9}{|c|}{ Ability to manage a collaborative project that involves early engagement of key stakeholders } \\
\hline Frequency & 43 & 25 & 17 & 11 & 0 & 96 & & \\
\hline Percent & 44.8 & 26.0 & 17.7 & 11.5 & 0 & 100 & 1.96 & 1.045 \\
\hline
\end{tabular}


Table 5: Association rules

\begin{tabular}{|l|l|r|l|r|r|r|}
\hline No & \multicolumn{1}{|c|}{ Antecedent } & \multicolumn{1}{|c|}{ Consequent } & \multicolumn{1}{|c|}{$\begin{array}{c}\text { Support } \\
(\%)\end{array}$} & $\begin{array}{c}\text { Confidence } \\
(\%)\end{array}$ & Lift \\
\hline 1 & BIM awareness & $==>$ & $\begin{array}{l}\text { Collaborative project } \\
\text { ability }\end{array}$ & 56.25 & 93.10 & 1.11 \\
\hline 2 & Collaborative project ability & $==>$ & BIM awareness & 56.25 & 67.50 & 1.11 \\
\hline 3 & IT Management ability & $==>$ & $\begin{array}{l}\text { Collaborative project } \\
\text { ability }\end{array}$ & 45.83 & 80.00 & 0.96 \\
\hline 4 & Collaborative project ability & $==>$ & IT Management ability & 45.83 & 55.00 & 0.96 \\
\hline 5 & $\begin{array}{l}\text { Collaborative project } \\
\text { participation }\end{array}$ & $==>$ & $\begin{array}{l}\text { Collaborative project } \\
\text { ability }\end{array}$ & 41.66 & 97.56 & 1.17 \\
\hline 6 & Micro & $==>$ & $\begin{array}{l}\text { Collaborative project } \\
\text { ability }\end{array}$ & 41.66 & 83.33 & 1.00 \\
\hline 7 & Collaborative project ability & $==>$ & Micro company & 41.66 & 50.00 & 1.00 \\
\hline 8 & Collaborative project ability & $==>$ & $\begin{array}{l}\text { Collaborative project } \\
\text { participation }\end{array}$ & 41.66 & 50.00 & 1.17 \\
\hline 9 & Private company & $==>$ & $\begin{array}{l}\text { Collaborative project } \\
\text { ability }\end{array}$ & 40.62 & 86.66 & 1.04 \\
\hline 10 & Collaborative project ability & $==>$ & Private company & 40.62 & 48.75 & 1.04 \\
\hline 11 & 3D outputs & $==>$ & $\begin{array}{l}\text { Collaborative project } \\
\text { ability }\end{array}$ & 37.50 & 87.80 & 1.05 \\
\hline 12 & Architecture & $==>$ & $\begin{array}{l}\text { Collaborative project } \\
\text { ability }\end{array}$ & 37.50 & 78.26 & 0.93 \\
\hline 13 & Collaborative project ability & $==>$ & 3D outputs & 37.50 & 45.00 & 1.05 \\
\hline 14 & Collaborative project ability & $==>$ & Architecture & 37.50 & 45.00 & 0.93 \\
\hline 15 & $\begin{array}{l}\text { Collaborative project } \\
\text { participation }\end{array}$ & BIM awareness & 85.36 & 1.41 \\
\hline
\end{tabular}

